\title{
Influence of Conditioned Media of Halomonas sp. DH-e on Phycosphere Bacterial Community Dynamics of Prorocentrum donghaiense
}

\author{
Xiao Bï, Aixia Wang", Hongzhi Han, Liling Xie*, Di Wang, \\ Guangyao Han, Lin Zhu, Yankun Zhu \\ Department of Biology, College of Science, Shantou University, Guangdong Shantou, People's Republic of China
}

Received: 4 April 2019

Accepted: 8 September 2019

\begin{abstract}
Prorocentrum donghaiense has become one of the major algae that cause phytoplankton blooms. A marine bacterium, Halomonas sp. DH-e with high algicidal activity to $P$. donghaiense was isolated in previous studies. However, the mechanism underlying the algicidal activity of DH-e was unknown. In the present study, the post-culture medium of DH-e was supplemented into the culture of $P$. donghaiense. Samples of algae cells and phycosphere bacteria were collected at different times. Illumina Miseq sequencing was used to evaluate bacterial community dynamics in the phycosphere of microalgae. Taxonomic analysis identified 3 phyla, including Proteobacteria, Bacteroidetes and Verrucomicrobia, with Proteobacteria dominating and accounting for more than $95 \%$ of all bacterial species. Alteromonadaceae increased gradually, while Rhodobacteraceae decreased during the culture with the post-culture medium. Principal component analysis suggested that bacterial community composition was similar during 0-12 h, but changed significantly at $24 \mathrm{~h}, 36 \mathrm{~h}$ and $48 \mathrm{~h}$. Redundancy analysis revealed a close correlation between phycosphere bacterial community composition and $\mathrm{pH}$, chlorophyll a and algae cell mass. In conclusion, the results suggested that algicidal activity of DH-e was mediated via the secretion of unidentified components in the post-culture medium, which induced variation of phycosphere bacterial community and subsequently contributed to the lysis of algae cells.
\end{abstract}

Keywords: algicidal bacteria, phycosphere bacteria, Illumina Miseq sequencing, Prorocentrum donghaiense

\#Authors who contributed equally and should be considered co-first authors *e-mail: 1lxie@stu.edu.cn 


\section{Introduction}

There are many close interactions between bacterioplankton and phytoplankton dynamics in aquatic systems [1], in which the extracellular products of photosynthetic algae stimulate the bacterial growth [2] and in return the marine bacteria have abilities to promote or inhibit phytoplankton growth [3-4]. This intimate microenvironment between algal cells and bacteriawas is defined as 'Phycosphere' [5].

Phytoplankton-bacteria interactions are multifarious [8] and often highly sophisticated and can span the spectrum of ecological relationships from cooperative to competitive [6]. At the simplest level, the relationship between these organisms is based on resource provision and can be either reciprocal or exploitative in nature. Aquatic heterotrophic bacteria obtain a large, albeit variable, fraction of their carbon demand directly from phytoplankton [7], with up to $50 \%$ of the carbon that is fixed by phytoplankton is ultimately consumed by bacteria [9-10]. Bacterial consumption of phytoplanktonderived organic material primarily involves the assimilation of the large quantities of typically highly labile, dissolved organic carbon (DOC) released by phytoplankton cells into the surrounding water column [11-12], but also includes the consumption of more complex algal products (for example, mucilage and polysaccharides) and senescent or dead phytoplankton biomass [13-15].

To understand the close relationship between $P$. donghaiense and its bacteria [16-17], we used Illumina Miseq sequencing of the V3-V4 regions of the 16S rRNA gene to explore the bacterial communities during the culture of $P$. donghaiense with the postculture medium of DH-e. The results showed that phycosphere bacterial community composition changed significantly during the culture, and a close correlation could be found with $\mathrm{pH}$, chlorophyll a and algae cell mass.

\section{Materials and Methods}

\section{Bacterial and Algae Strains and Conditions of Cultivation}

The algicidal bacterium, Halomonas sp. DH-e, was isolated from red tide areas in the Zhejiang coast, and identified as having efficient algicidal activity on $P$. donghaiense by means of secreting extracellular substance. $100 \mu \mathrm{L}$ of the strain were inoculated in $50 \mathrm{~mL}$ LB medium (tryptone $10 \mathrm{~g}$, yeast extract $5 \mathrm{~g}$, fixed capacity to $1 \mathrm{~L}$ using seawater, $\mathrm{pH} 7.2$ ) at $28^{\circ} \mathrm{C}$ with shaking at $160 \mathrm{r} / \mathrm{min}$ [15]. It has been deposited in the China National Culture Collection Centre (No. CCTCC NO: M2014541). The accession number at GenBank are KP144872. (GenBank: www.ncbi.nlm.nih.gov/Genbank/ submit.html)
P. donghaiense were provided by the College of Life Science and Technology, Jinan University. The algae were cultured in $\mathrm{f} / 2$ culture medium (without silicate) at $20 \pm 1^{\circ} \mathrm{C}$ [18] under a 12:12 h light-dark cycle with a light intensity of 4000 Lux.

\section{Sample Collection}

After culturing for 5 days, the bacterial culture was centrifuged at $4000 \mathrm{rpm}$ for $15 \mathrm{~min}$, and supernatant was collected and filtered through $0.22 \mu \mathrm{m}$ diameter pore-size filters for three times. The above supernatant was used as the post-culture medium and added into the $300 \mathrm{~mL}$ logarithmic $P$. donghaiense cultures in $1.0 \%$ final concentration. Three parallel samples of algae cells and phycosphere bacteria were collected at 0,12 , 24,36 and $48 \mathrm{~h}$ by filtering the culture through $0.22 \mu \mathrm{m}$ membrane. The collected samples were designated as S1 1, S1 2, S1 3 for $0 \mathrm{~h}, \mathrm{~S} 21$, S2 2, S2 3 for $12 \mathrm{~h}$, $\mathrm{S} 3 \mathrm{1}, \mathrm{S} 32$ 2, S3 3 for $24 \mathrm{~h}, \mathrm{~S} 4$ 1, S4 2, S4 3 for $36 \mathrm{~h}$, $\mathrm{S} 5 \_1, \mathrm{~S} 5 \_2, \mathrm{~S} 5 \_3$ for $48 \mathrm{~h}$. The samples were stored in a freezer at $-80^{\circ} \mathrm{C}$.

\section{Measurement of Environmental Parameters}

In order to obtain the environmental parameters, the concentrations of total nitrogen (TN), total phosphorus (TP), ratio of nitrogen to phosphorus (N/P), chlorophyll a (Chl a) of $P$. donghaiense cultures [19] and the density of algae cells (DAC) were measured according to standard methods [20]. The P. donghaiense cells were dyed with Lugol's iodine and the number of cells were counted under an optical microscope.

\section{DNA Extraction, PCR Amplification and Sequencing}

DNA was extracted using a soil DNA kit (OMEGA, USA) according to the manufacturer's protocol. The DNA concentration and quality were determined by agarose gel electrophoresis $(1 \% \mathrm{wt} / \mathrm{vol}$ agarose in Trisacetate-EDTA buffer) and using a NanoDrop 2000 spectrophotometer (Thermo Scientifc, USA). DNA was stored at $-20^{\circ} \mathrm{C}$ until used for PCR amplification.

A fragment of the 16S rRNA gene was amplified using the universal primers $338 \mathrm{~F}$ (5'-ACTCCTACGGGAGGCAGCAG-3') [21] and 806R (5'-GGACTACHVGGGTWTCTAAT-3') [22], covering the V3-V4 hyper-variable region, 15 libraries were constructed and sequenced using the Illumina MiSeq sequencing platform PE300. The sequencing was performed at Majorbio Biomedical Technology Co., Ltd, Shanghai, China.

\section{Data Analysis}

Quality control was performed on the raw data. The reads were processed by removing tags and primer, 
accepted only reads with a mean quality score above 20 and read lengths more than $245 \mathrm{bp}$. Sequences with more than one ambiguous base call were removed using a Ribosomal Database Project sequencing pipeline (RDP) [23-24]. The data of chloroplast and mitochondria were eliminated, and the resulting sequences were used for final analysis. The sequence with similarity greater than 0.97 was categorized as an operational taxonomic unit (OTU). The number of OTUs contained in each sample was analyzed and the rarefaction curve was drawn. The diversity and richness of the samples were studied by calculating the Simpson, Shannon, Chao and Ace indexes [25-26] with MOTHUR version v.1.30.1 [27].

The community structure was analyzed at the phylum and the family levels. Principal component analysis (PCA) results were displayed using the vegan package, and the figures were draw using ggplot2 packange in $\mathrm{R}$ [28-29]. Linear discriminant analysis (LDA) was performed using the online LEfSe Program. Significant differences in abundance between groups were identified.

The correlations between microbial communities and environmental factors were analyzed with ordination methods using CANOCO software for Windows, version 4.5. Redundancy analysis (RDA) was used to illustrate the relationship between microbiota and environment factors because detrended correspondence analysis run on the bacterial OUT ( $97 \%$ similarity) profile matrix indicated that the length of the first axis was $<3$. The environmental factors were normalized and served as the environmental input.
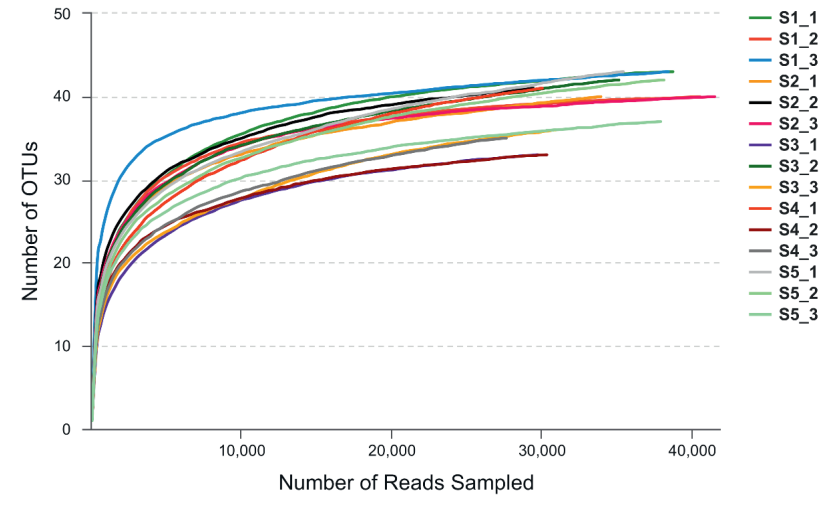

Fig. 1. Rarefaction curves of operational taxonomic units (OTUs) sharing $\geq 97 \%$ similarity for the 15 samples. Samples were treated with the post-culture medium for $0 \mathrm{~h}$ (S1_1, S1_2, $\left.\mathrm{S} 1 \_3\right), 12 \mathrm{~h}\left(\mathrm{~S} 2 \_1, \mathrm{~S} 2 \_2, \mathrm{~S} 2 \_3\right), 24 \mathrm{~h}\left(\mathrm{~S} 3 \_1, \mathrm{~S} 3 \_2, \mathrm{~S} 3 \_3\right), 3 \overline{6} \mathrm{~h}$ (S4_1, S4_2, S4_3), $48 \mathrm{~h}\left(\mathrm{~S} 5 \_1, \mathrm{~S} 5 \_2, \mathrm{~S} 5 \_3\right)$.

\section{Results}

General Analyses of Illumina Miseq Sequencing Data

After filtering the low-quality reads and removing all chloroplast/mitochondrial sequences and rarefying the datasets, 30,761 to 44,321 effective sequences were collected from each sample, resulting in a total of 564,527 sequences and 47 OTUs with $\geq 97 \%$ sequence similarity from the 15 samples. The coverage ranged

Table 1. Number of reads, observed diversity richness (OTUs), estimated OTU richness (Ace and Chao), diversity index (Shannon and Simpson) and estimated sample coverage for $16 \mathrm{~S}$ rRNA libraries of the 15 samples. Samples were treated with CM for 0 h (S1_1, S1_2, $\left.\mathrm{S} 1 \_3\right), 12 \mathrm{~h}\left(\mathrm{~S} 2 \_1, \mathrm{~S} 2 \_2, \mathrm{~S} 2 \_3\right), 24 \mathrm{~h}\left(\mathrm{~S} 3 \_1, \mathrm{~S} 3 \_2, \mathrm{~S} 3 \_3\right), 36 \mathrm{~h}\left(\mathrm{~S} 4 \_1, \mathrm{~S} 4 \_2, \mathrm{~S} 4 \_3\right), 48 \mathrm{~h}$ (S5_1, S5_2, S5_3).

\begin{tabular}{|c|c|c|c|c|c|c|c|}
\hline Samples & Reads & OTUs & Coverage (\%) & Ace & Chao & Shannon & Simpson \\
\hline S1_1 & 40602 & 43 & 99.99 & 44.20 & 43.60 & 0.55 & 0.83 \\
\hline S1_2 & 43967 & 40 & 99.99 & 41.46 & 41.00 & 0.62 & 0.79 \\
\hline S1_3 & 42395 & 43 & 99.99 & 47.50 & 44.50 & 1.13 & 0.61 \\
\hline S2_1 & 35729 & 40 & 99.98 & 45.65 & 45.00 & 0.72 & 0.75 \\
\hline S2_2 & 31226 & 41 & 99.98 & 44.91 & 43.50 & 0.76 & 0.74 \\
\hline S2_3 & 44321 & 40 & 99.99 & 41.80 & 43.00 & 0.72 & 0.75 \\
\hline S3_1 & 32010 & 33 & 99.99 & 34.77 & 33.50 & 0.77 & 0.65 \\
\hline S3_2 & 39070 & 42 & 99.98 & 48.54 & 49.00 & 1.17 & 0.47 \\
\hline S3_3 & 33531 & 36 & 99.98 & 43.89 & 41.25 & 0.93 & 0.52 \\
\hline S4_1 & 33545 & 41 & 99.97 & 48.68 & 50.33 & 1.04 & 0.45 \\
\hline S4_2 & 33943 & 33 & 99.99 & 35.92 & 34.50 & 1.02 & 0.44 \\
\hline S4_3 & 30761 & 35 & 99.97 & 52.38 & 38.50 & 1.02 & 0.44 \\
\hline S5_1 & 39982 & 43 & 99.98 & 51.09 & 47.67 & 1.18 & 0.42 \\
\hline S5_2 & 41313 & 42 & 99.98 & 46.79 & 46.20 & 1.07 & 0.44 \\
\hline S5_3 & 42132 & 37 & 99.99 & 40.19 & 40.33 & 1.02 & 0.45 \\
\hline
\end{tabular}



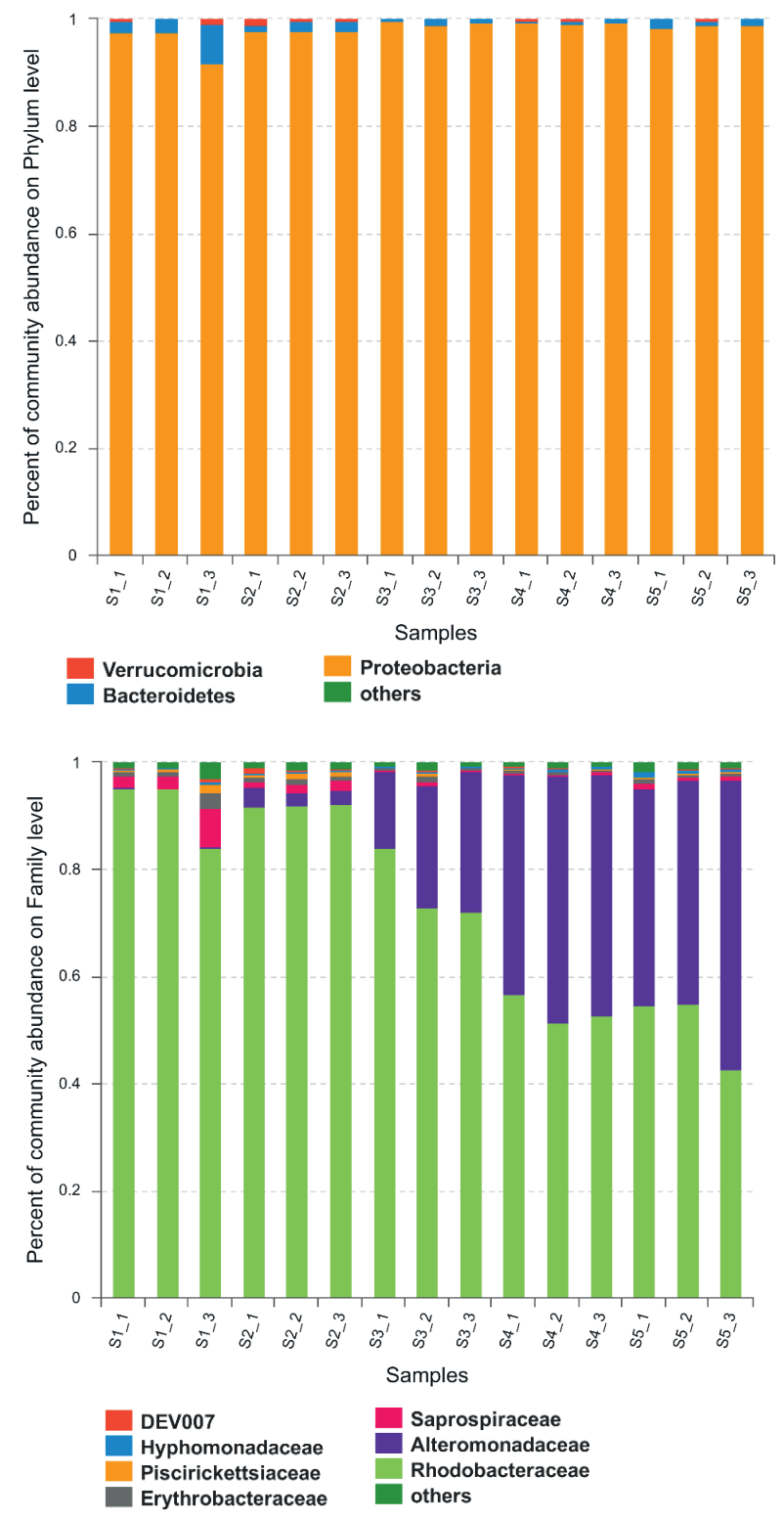

Fig. 2. Taxonomic classification of the sequencing reads at the phylum and family levels. Samples were treated with the postculture medium for $0 \mathrm{~h}\left(\mathrm{~S} 1 \_1, \mathrm{~S} 1\right.$ 2, S1 3), $12 \mathrm{~h}$ (S2 1, S2 2, S2_3), 24 h (S3_1, S3_2, S3_3), 36 h (S4_1, S4_2, S4_3), 48 h (S5_1, S5 2, S5 3). from $99.97 \%$ to $99.99 \%$, indicating that almost all bacteria in the samples were identified in this study (Table 1). The rarefaction curves tended to reach the saturation plateau when the number of sequences reached 30000-40000, indicating that the sequencing depth was enough to cover all bacteria and reflect the diversity (Fig. 1).

The microbial complexity was estimated with alpha-diversity indices (Ace, Chao, Shannon and Simpson). The Shannon index increased and Simpson index decreased during treatment with no significant difference of bacterial community composition detected at $0 \mathrm{~h}$ and $12 \mathrm{~h}$ (Student's t test, $P>0.05$ ). However, there were significant variations among samples of other time points (Student's t test, $P<0.05$ ). Ace, Chao indices and the number of OTUs changed indistinctively (Student's t test, $P>0.05$ ) (Table 1). The results indicated that bacterial diversity of the phycosphere increased when the post-culture medium from DH-e was added.

\section{Composition of Phycosphere Bacterial Community}

The phycosphere bacteria community of $P$. donghaiense was mainly composed of 3 phyla, including Proteobacteria, Bacteroidetes and Verrucomicrobia. The dominant bacterial phylum was Proteobacteria, which accounts for more than 95\%. Furthermore, the phylogenetic classification of sequences from the samples resulted in 7 different families, including Rhodobacteraceae, Alteromonadaceae, Saprospiraceae, Erythrobacteraceae, Piscirickettsiaceae, Hyphomicrobiaceae and DEV007 (Fig. 2). Although Rhodobacteraceae predominated the bacterial community during the whole cultivation, the abundance decreased from $91.6 \%$ to $50.7 \%$. On the other hand, the relative abundance of Alteromonadaceae increased from $0.13 \%$ to $45.6 \%$.

A metagenomic analysis was performed using the linear discriminant analysis effect size (LEfSe) tool [30] (Fig. 3). We noted a significant enrichment (LDA score, 3.0) of OTU24 (Saprospiraceae, norank

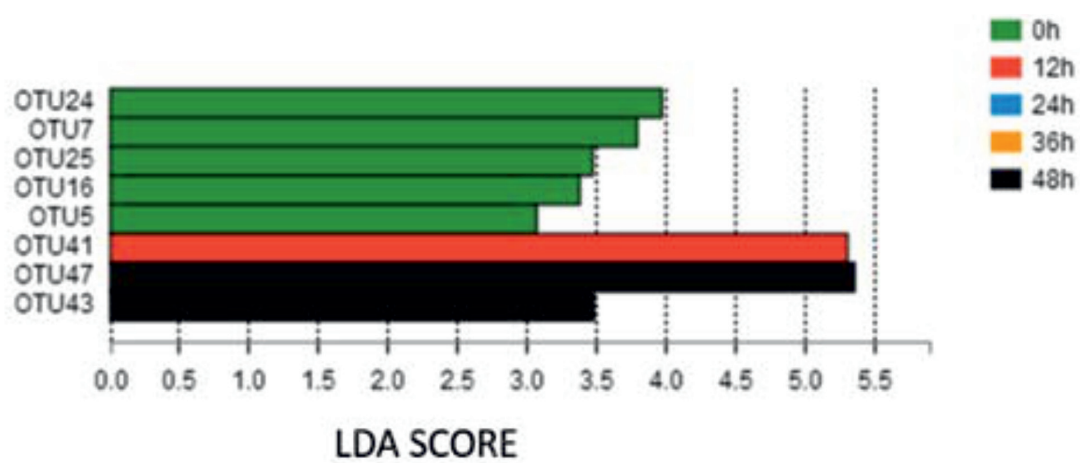

Fig. 3. Linear discriminant analysis (LDA) coupled with effect size measurements identifies the differentially abundant species among different samples. Only taxa exceeding an LDA threshold of 3.0 were considered for analysis. Green, taxa enriched in the $0 \mathrm{~h}$ library; red, taxa enriched in the $12 \mathrm{~h}$ library; and black, taxa enriched in the $48 \mathrm{~h}$ library. 


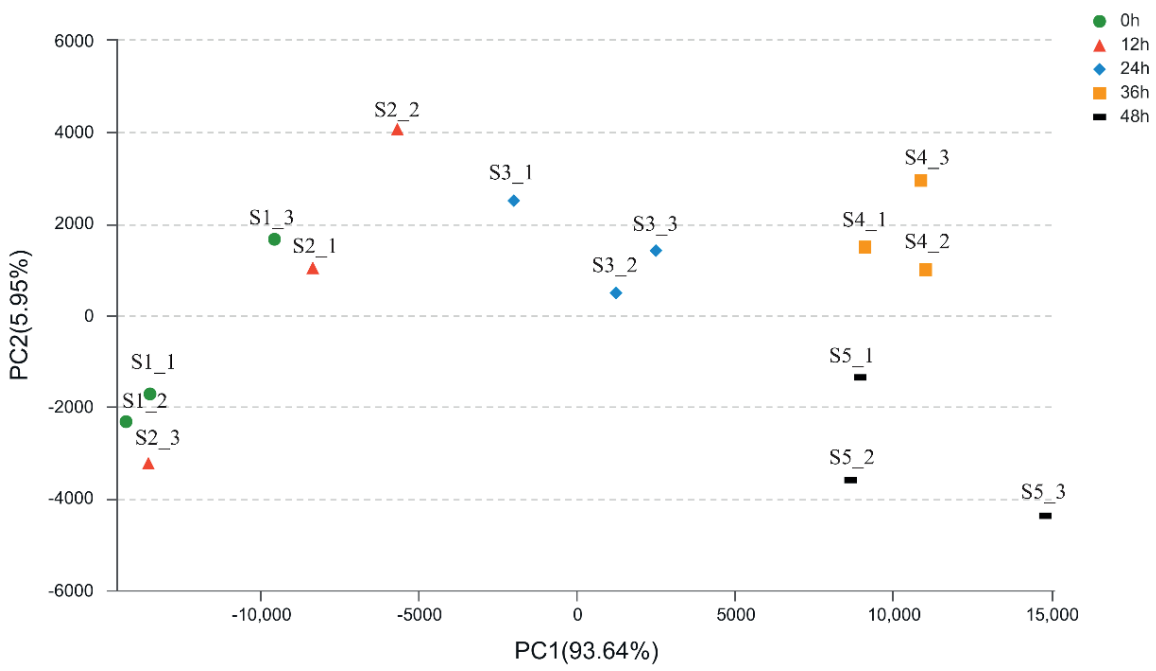

Fig. 4. Principle component analysis of bacterial communities during the algicidal process effected by the post-culture medium. Samples were treated with the post-culture medium for $0 \mathrm{~h}\left(\mathrm{~S} 1 \_1, \mathrm{~S} 1 \_2, \mathrm{~S} 1 \_3\right), 12 \mathrm{~h}\left(\mathrm{~S} 2 \_1, \mathrm{~S} 2 \_2, \mathrm{~S} 2 \_3\right), 24 \mathrm{~h}\left(\mathrm{~S} 3 \_1, \mathrm{~S} 3 \_2, \mathrm{~S} 3 \_3\right), 36 \mathrm{~h}\left(\mathrm{~S} 4 \_1\right.$, S4_2, S4_3), 4 8h (S5_1, S5_2, S5_3).

\section{Saprospiraceae), OTU7 (Saprospiraceae, Phaeodactylibacter), OTU25 (Piscirickettsiaceae, Methylophaga), OTU16 (Rhodobacteraceae, unclassified Rhodobacteraceae), OTU5 (Rhodobacteraceae, unclassified_Rhodobacteraceae) in the $0 \mathrm{~h}$ library, OTU41 (Rhodobacteraceae, Marivita) in the $12 \mathrm{~h}$ library and OTU47 (Alteromonadaceae, Alteromonas) and OTU43 (Hyphomonadaceae, Maricaulis) in the $48 \mathrm{~h}$ library. \\ Principal Component Analysis and Correlation Analysis of the Bacterial Community Shift}

The PCA results emphasized the differences of bacterial populations among the groups treated with the post-culture medium for different periods of time (Fig. 4). The first and second PCs respectively accounted for $93.64 \%$ and $5.95 \%$ respectively of the total variation. Scatter plots based on $\mathrm{PCl}$ and $\mathrm{PC} 2$ values showed that all samples were clustered into four groups: I, including $\mathrm{S} 11_{1}, \mathrm{~S} 11_{2}, \mathrm{~S} 11_{3}$, S2 1, S2_2 and S2_3; II, including S3_1, S3_2 and S3_3; III, including S4_1, S4_2 and S4_3; and IV including S5_1, S5_2 and S5 3. The bacterial communities of the groups treated with the post-culture medium for $0 \mathrm{~h}$ showed great similarity to that for $12 \mathrm{~h}$. The samples treated with the post-culture medium for 24, 36 and $48 \mathrm{~h}$ were clustered into three groups. The results suggested that the post-culture medium had significant influence on the bacterial community during the culture.

\section{Environmental Characterization}

Table 2 lists the environmental parameters. There was slight variation in $\mathrm{pH}, \mathrm{TN}, \mathrm{TP}$ and $\mathrm{N} / \mathrm{P}$ ratio after incubation with the post-culture medium. The initial $\mathrm{pH}$ and TP of $P$. donghaiense were 8.18 and $1.12 \mu \mathrm{g} / \mathrm{mL}$, which decreased to 7.2 and $0.96 \mu \mathrm{g} / \mathrm{mL}$ respectively after treatment with the post-culture medium for 48 h. Conversely, TN and N/P increased from $10.9 \mu \mathrm{g} / \mathrm{mL}$ and 9.9 to $11.1 \mu \mathrm{g} / \mathrm{mL}$ and 11.7 respectively after $48 \mathrm{~h}$. The density of algae cells and concentration of $\mathrm{Chl}$ a reduced significantly owing to the algicidal effect of the post-culture medium. The density of algae cells decreased from $2.53 \times 10^{6}$ cells $/ \mathrm{mL}$ to 0 cells $/ \mathrm{mL}$ after $36 \mathrm{~h}$.

\section{Relationship Between Microbial Community and Environmental Parameters}

Microbial community structure is not only regulated by biological factors, but also is closely related to environmental factors. In order to determine what environmental characteristics affected the bacterial community at the family level, the relationship between bacterial community composition and environmental characteristic was analyzed by RDA (Fig. 5). The results indicated that $\mathrm{pH}, \mathrm{TP}, \mathrm{Chl}$ a and $\mathrm{DAC}$ significantly contributed to the variation of bacterial communities $(P<0.01)$, while TN and N/P had almost no correlation $(P>0.05)$. The family Rhodobacteraceae was positively correlated to $\mathrm{pH}, \mathrm{Chl}$ a and $\mathrm{DAC}$, whereas Alteromonadaceae had negative correlations.

The group treated for $0 \mathrm{~h}\left(\mathrm{~S} 1 \_1, \mathrm{~S} 1 \_2, \mathrm{~S} 1 \_3\right)$ and the group treated for $12 \mathrm{~h}\left(\mathrm{~S} 2{ }_{1}, \mathrm{~S} 2 \overline{2}, \mathrm{~S} 2 \overline{3}\right)$ were located promiscuously in the ordination diagram. These two groups were positively correlated with $\mathrm{pH}$, $\mathrm{TN}, \mathrm{TP}, \mathrm{Chl} \mathrm{a}$, and DAC, and negatively correlated with N/P. Samples treated for $24 \mathrm{~h}$ (S3_1, S3_2, S3_3) were positively correlated with TN and TP, and negatively correlated with N/P. Samples treated for 36 h (S4 1, S4 2, S4 3) and samples of 48 h (S5 1, S5 2, S5_3) were located closely in the ordination diagram. 
Table 2. Environmental variables from $15 \mathrm{P}$. donghaiense cultures treated with the post-culture medium for $0 \mathrm{~h}\left(\mathrm{~S} 1 \_1, \mathrm{~S} 1 \_2, \mathrm{~S} 1 \_3\right), 12 \mathrm{~h}$ (S2_1, S2_2, S2_3), $24 \mathrm{~h}\left(\mathrm{~S} 3 \_1, \mathrm{~S} 3 \_2, \mathrm{~S} 3 \_3\right), 36 \mathrm{~h}\left(\mathrm{~S} 4 \_1, \mathrm{~S} 4 \_2, \mathrm{~S} 4 \_3\right), 48 \mathrm{~h}\left(\mathrm{~S} 5 \_1, \mathrm{~S} 5 \_2, \mathrm{~S} 5 \_3\right)$.

\begin{tabular}{|c|c|c|c|c|c|c|}
\hline Samples & $\mathrm{pH}$ & $\mathrm{TN}(\mu \mathrm{g} / \mathrm{mL})$ & $\mathrm{TP}(\mu \mathrm{g} / \mathrm{mL})$ & $\mathrm{N} / \mathrm{P}$ & $\mathrm{Chl}$ a $(\mu \mathrm{g} / \mathrm{mL})$ & DAC $\left(\times 10^{5}\right.$ cells $\left./ \mathrm{mL}\right)$ \\
\hline $\mathrm{S} 1 \_1$ & 8.33 & 10.93 & 1.12 & 9.72 & 0.021 & 25 \\
\hline $\mathrm{S} 1 \_2$ & 8.06 & 11.07 & 1.21 & 9.11 & 0.016 & 27 \\
\hline $\mathrm{S} 1 \_3$ & 8.16 & 11.00 & 1.01 & 10.86 & 0.018 & 24 \\
\hline $\mathrm{S} 2 \_1$ & 8.18 & 11.11 & 1.03 & 10.74 & 0.031 & 21 \\
\hline $\mathrm{S} 2 \_2$ & 8.13 & 11.28 & 1.10 & 10.23 & 0.030 & 19 \\
\hline $\mathrm{S} 2 \_3$ & 8.22 & 11.23 & 1.03 & 10.92 & 0.035 & 17 \\
\hline S3_1 & 7.62 & 11.09 & 1.12 & 9.87 & 0.014 & 9 \\
\hline S3_2 & 7.55 & 10.90 & 1.02 & 10.67 & 0.008 & 10 \\
\hline S3_3 & 7.66 & 11.08 & 1.10 & 10.07 & 0.009 & 8 \\
\hline S4_1 & 7.29 & 11.05 & 1.04 & 10.68 & 0.007 & 0 \\
\hline S4_2 & 7.24 & 10.98 & 1.09 & 10.03 & 0.010 & 0 \\
\hline S4_3 & 7.19 & 11.05 & 1.05 & 10.52 & 0.004 & 0 \\
\hline S5_1 & 7.23 & 11.00 & 1.04 & 10.59 & 0.005 & 0 \\
\hline S5_2 & 7.18 & 11.08 & 0.80 & 13.87 & 0.002 & 0 \\
\hline S5_3 & 7.2 & 11.02 & 1.04 & 10.65 & 0.003 & 0 \\
\hline
\end{tabular}

Abbreviations: TN, total nitrogen; TP, total phosphorus; N/P, ratio of nitrogen to phosphorus; Chl a, chlorophyll a; DAC, density of algae cells

These two groups were positively correlated with N/P and negatively correlated with $\mathrm{pH}, \mathrm{TN}, \mathrm{TP}, \mathrm{Chl}$ a and DAC.

\section{Discussion}

\section{Variation of Phycosphere Bacterial Community of $P$. donghaiense}

Ace, Chao, Shannon and Simpson indices were used to estimate microbial community diversity [31]. Our results showed that Shannon and Simpson indices had significant difference, indicating that the bacterial diversity increased during the culture. It was already known that algae cells can release dissolved organic carbon (DOC) to phycosphere, and the concentration of DOC remains high even when algae cells were lysed [32-33]. Some bacteria in the phycosphere, like Proteobacteria and Bacteroidetes, can use these substrates as carbon sources [34-36]. It was not difficult to explain why Proteobacteria dominated $(>95 \%)$. As reported by many researchers, Proteobacteria, Bacteroidetes, Verrucomicrobia and Actinobacteria were found mostly in coastal areas or the phycosphere [11, 37-38]. However, only a minor fraction of sequences $(<5 \%)$ identified in our study were Bacteroidetes and Verrucomicrobia, which have been shown to be associated with phytoplankton [39]. At the family level, the most abundant bacteria were Rhodobacteraceae and Alteromonadaceae. Interestingly, the abundance of Alteromonadaceae increased and Rhodobacteraceae decreased during the lysis of algal cells. It has been reported that Rhodobacteraceae could benefit from phytoplankton bloom and its relative abundance had positive correlation with $\mathrm{Chl}$ a concentration [40]. Our results drew a similar conclusion, which showed that the density of algae cells and $\mathrm{Chl}$ a concentration reduces gradually during the algicidal process due to algae cell lysis (Table 1), and Rhodobacteraceae was positively correlated with $\mathrm{Chl}$ a and DAC (Fig. 5). Increasingly low $\mathrm{Chl}$ a concentration was correlated with the decrease of Rhodobacteraceae (Table 1). A large amount of DOC was released during algae cell lysis [41]. Alteromonadaceae could rapidly respond to the disturbance and profited from allochthonous carbon input [40], explaining the increased abundance in the anaphase of algicidal process (Fig. 3). It was worth mentioning that the most common algicidal bacteria reported in the literature were Proteobacteria, including Alteromonas or the Bacteroides [11, 42]. If the concentration of Alteromonadaceae has not reach an effective killing density, the compound contained in conditioned media may stimulate the growth of Alteromonadaceae. We speculated that the increase of Alteromonadaceae and the lysis of algae cells form a positive feedback loop. Our speculation was confirmed by PCA results, which demonstrated that samples were clustered into four groups with variation tendency of bacterial flora. Behrenfeld et al. [43] and Chen et al. [44] 


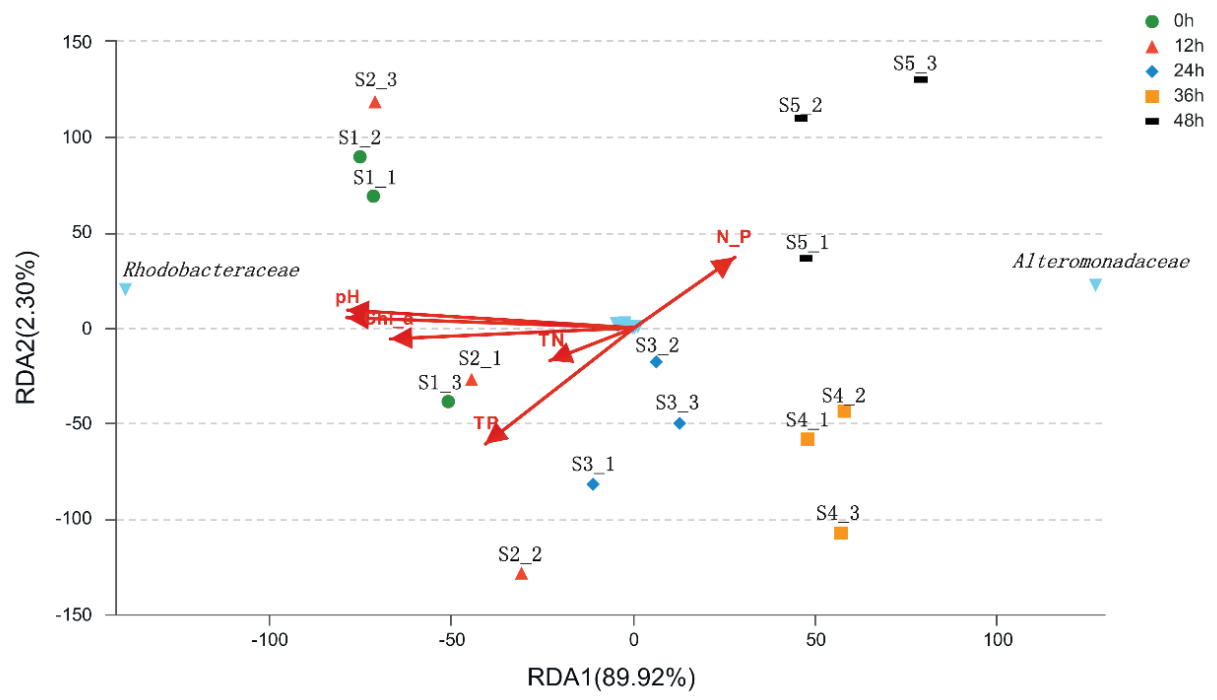

Fig. 5. Redundancy analysis (RDA) ordination diagram showing the relationship among samples, bacteria and environmental factors. TN, total nitrogen; TP, total phosphorus; N/P, ratio of nitrogen to phosphorus; Chl a, chlorophyll a; DAC, the density of algae cells.

proposed that bacterial community compositions were resilient to phytoplankton blooms to a certain extent, whereas our results showed that bacterial community compositions changed irreversibly after treatment with conditioned media. Collectively, our results supported bacterial community interactions that were crucial factors and that regulated the growth and death of algae cells, and we speculated that the variation of bacterial community composition was one of the factors that induced the lysis of algae cells.

\section{Relationship Between Bacterial Community Composition and Environmental Factors}

The density of algae cells and Chl a concentration was reduced gradually during the algicidal process because of the algae cell lysis (Table 1). Moreover, $\mathrm{pH}$ reduced gradually and the water samples changed from alkaline to neutral. The $\mathrm{pH}$ of samples increased in the initial state because algae cells could maintain photosynthesis in low $\mathrm{CO}_{2}$ condition when the number of algae cells were high; however, $\mathrm{pH}$ turned increasingly lower as the algae cell number became less and less under the influence of conditioned media [44]. Consistently, the samples treated with conditioned media for $0 \mathrm{~h}$ and $12 \mathrm{~h}$ were positively correlated with $\mathrm{pH}, \mathrm{Chl}$ a and DAC. However, the samples treated with conditioned media for $36 \mathrm{~h}$ and $48 \mathrm{~h}$ were negatively correlated with these indices. TN and TP of samples showed no significant variation $(P>0.05)$ on account of the consumption of nitrogen and phosphorus by algae cells, and the release by lytic algae cells simultaneously [11]. Consistently, the bacterial community compositions had no correlation with TN and TP $(P>0.05)$.

What's more, Rhodobacteraceae and Alteromonadaceae had a strong oppositional correlation because Rhodobacteraceae was positively correlated with $\mathrm{pH}, \mathrm{Chl}$ a and DAC, while Alteromonadaceae was negatively correlated with them. The result was also consistent with the report that Rhodobacteraceae could benefit from phytoplankton bloom and its relative abundance had a positive correlation with $\mathrm{Chl}$ a [40].

In conclusion, we isolated Halomonas sp. DH-e, which had an algicidal effect on $P$. donghaiense from China's Zhejiang coast in previous studies. In the present study, the results showed that bacterial community composition in phycosphere of $P$. donghaiense was influenced by conditioned media of Halomonas sp. DH-e. We demonstrated that phycosphere bacterial community structure shifted dynamically and the diversity varied with the treatment time extended. Proteobacteria was a core microbial community due to its higher relative abundances than others. Interestingly, the abundances of Alteromonadaceae increased and Rhodobacteraceae decreased significantly as treatment time was prolonged. We speculated that the increasing concentration of Alteromonadaceae and the lysis of algae cells formed a positive feedback loop and that the bacterial community composition played a significant role in the lysis of algae cells.

\section{Acknowledgements}

This work was supported by the National Natural Science Foundation of China under contract No. 41230961 and the Open Fund Project of Marine Biotechnology Key Laboratory of Guangdong Province in China under contract GPKLMB2. 01201. We thank Prof. Yang Weidong from Jinan University and Prof. Wang Dazhi from Xiamen University in China for their assistance. 


\section{Conflict of Interest}

The author declares no conflict of interest.

\section{References}

1. MINGMING H., YANHUI L., YUCHUN W., HUAIDONG Z., YONGDING L., GAOFENG Z. Phytoplankton and bacterioplankton abundances and community dynamics in Lake Erhai[J]. Water Science \& Technology. 68 (2), 348, 2013.

2. CHO D.H., RAMANAN R., HEO J., LEE J., KIM B.H., $\mathrm{OH}$ H.M., KIM H.S. Enhancing microalgal biomass productivity by engineering a microalgal-bacterial community. Bioresource Technology. 175, 578, 2015.

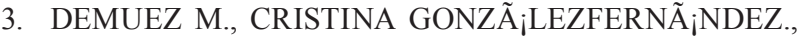
BALLESTEROS M. Algicidal microorganisms and secreted algicides: New tools to induce microalgal cell disruption[J]. Biotechnology Advances. 33 (8), 1615, 2015.

4. SUN R., SUN P., ZHANG J., SOFIA ESQUIVELELIZONDOC., YONGHONG W. Microorganisms-based methods for harmful algal blooms control: A review[J]. Bioresource Technology. 248 (Pt B), 2017.

5. ZHAI C.M., LIU C.H., LYU L. Interaction between Microcystis aeruginosa and bacterium Ma-B1 strain within phycosphere[J]. Research of Environmental Sciences. 27 (7), 704, 2014.

6. AMIN S.A., HMELO L.R., VAN TOL H.M., DURHAM, B.P., CARLSON L.T., HEAL, K.R. Interaction and signalling between a cosmopolitan phytoplankton and associated bacteria[J]. Nature, 522 (7554), 98, 2015.

7. FOUILLAND E., TOLOSA I., BONNET D., BOUVIER C., BOUVIER T., BOUVY M., GOT P., LE FLOC'H E., MOSTAJIR B., ROQUES C., SEMPERE R., SIME-NGANDO T., VIDUSSI F. Bacterial carbon dependence on freshly produced phytoplankton exudates under different nutrient availability and grazing pressure conditions in coastal marine waters. FEMS Microbiol. Ecol. 87, 757, 2014.

8. KROHNMOLT I., ALAWI M., FÖRSTNER K.U., WIEGANDT A., BURKHARDT L., INDENBIRKEN D. Insights into Microalga and Bacteria Interactions of Selected Phycosphere Biofilms Using Metagenomic, Transcriptomic, and Proteomic Approaches[J]. Frontiers in Microbiology, 8, 1941, 2017.

9. LURIA C.M., AMARALZETTLER L.A., DUCKLOW H.W., REPETA D.J., RHYNE A.L., RICH J.J. Seasonal shifts in bacterial community responses to phytoplanktonderived dissolved organic matter in the western antarctic peninsula. Frontiers in Microbiology, 8, 2017.

10. MCDONNELL A.M.P., LAM P.J., LAMBORG C.H., BUESSELER K.O., SANDERS R., RILEY J.S. The oceanographic toolbox for the collection of sinking and suspended marine particles. Progress in Oceanography, 133 (1), 17, 2015.

11. TAIPALE S.J., BRETT M.T., HAHN M.W., MARTINCREUZBURG D., YEUNG S., HILTUNEN M. Differing daphnia magna assimilation efficiencies for terrestrial, bacterial, and algal carbon and fatty acids. Ecology, 95 (2), $563,2016$.

12. REMBAUVILLE M., SALTER I., LEBLOND N., GUENEUGUES A., BLAIN S. Export fluxes in a naturally iron-fertilized area of the southern ocean - part 1: seasonal dynamics of particulate organic carbon export from a moored sediment trap. Biogeosciences, 12 (11), 3153, 2015.

13. HRDINKA T., VLASÃ $\tilde{i}_{K}$ P., HAVEL L., MLEJNSKÃ E. Possible impacts of climate change on water quality in streams of the czech republic. International Association of Scientific Hydrology Bulletin, 60 (2), 192, 2015.

14. LANDA M., BLAIN S., HARMAND J., MONCHY S., RAPAPORT A., OBERNOSTERER I. Major changes in the composition of a Southern Ocean bacterial community in response to diatom-derived dissolved organic matter. Fems Microbiology Ecology, 94 (8),2018.

15. HAN G.Y., XIE L.L., BI X., WU P.F., ZHOU L., ZHU Y.K. Inhibitory effect of metabolites from algicidal bacterium DH-e on Prorocentrum donghaiense. Journal of Applied Oceanography. 36 (2), 151, 2017.

16. SU X., STEINMAN A.D., TA NG X., XUE Q., ZHAO Y., XIE L. Response of bacterial communities to cyanobacterial harmful algal blooms in lake taihu, china. Harmful Algae, 68, 168, 2017.

17. EIGEMANN F., HILT S., SALKA I., GROSSART H.P. Bacterial community composition associated with freshwater algae: species specificity vs. dependency on environmental conditions and source community. Fems Microbiology Ecology. 83 (3), 650, 2013.

18. WANG D., XIE L.L., ZHU X.B., BI X., ZHENG Y.Z., ZHU Y.K. Study on the metabolites of DH-e, a Halomonas marine bacterium, against three toxic dinoflagellate species. Water Sci Technol. 78 (7), 1535, 2018.

19. HOU D., JIANG H., LÜ C., DONG S., WANG J., XIE, Z., ZHANG F. Spatial variations and distributions of phosphorus and nitrogen in bottom sediments from a typical north-temperate lake, china. Environmental Earth Sciences, 71 (7), 3063, 2014.

20. SAFAFAR H., WAGENEN J.V., MØLLER P., JACOBSEN C. Carotenoids, phenolic compounds and tocopherols contribute to the antioxidative properties of some microalgae species grown on industrial wastewater. Marine Drugs, 13 (12), 7339, 2015.

21. CAPORASO J.G., LAUBER C.L., WALTERS W.A., BERGLYONS D., LOZUPONE C.A., TURNBAUGH P.J., FIERER N., KNIGHT R. Colloquium paper: global patterns of 16s RNA diversity at a depth of millions of sequences per sample. Proceedings of the National Academy of Sciences of the United States of America. 108 (Supplement 1), 4516, 2011.

22. WANG P., CHEN B., ZHANG H. High throughput sequencing analysis of bacterial communities in soils of a typical poyang lake wetland. Acta Ecologica Sinica, 37 (5), 2017.

23. DOS SANTOS H.F., CURY J.C., DO CARMO F.L., DOS SANTOS A.L., TIEDJE J., VAN ELSAS J.D., ROSADO A.S., PEIXOTO R.S. Mangrove bacterial diversity and the impact of oil contamination revealed by pyrosequencing: Bacterial Proxies for oil pollution. Plos One. 6 (3), e16943, 2011.

24. TANG X., LI L., SHAO K., WANG B., CAI X., ZHANG L., CHAO J., GAO G. Pyrosequencing analysis of free- living and attached bacterial communities in Meiliang Bay, Lake Taihu, a large eutrophic shallow lake in China. Canadian Journal of Microbiology. 61 (1), 22, 2015.

25. FOUTS D.E., SZPAKOWSKI S., PURUSHE J., TORRALBA M., WATERMAN R.C. AND MACNEIL, M.D. Next generation sequencing to define prokaryotic 
and fungal diversity in the bovine rumen. Plos One. 7 (11), e48289, 2012.

26. BATES S.T., CLEMENTE J.C., FLORES G.E., WALTERS W.A., PARFREY L.W., KNIGHT R. AND FIERER N. Global biogeography of highly diverse protistan communities in soil. ISME Journal. 7 (3), 652, 2013.

27. RUNNEL K., TAMM H., LÕHMUS A. Surveying woodinhabiting fungi: most molecularly detected polypore species form fruit-bodies within short distances. Fungal Ecology, 18, 93, 2015.

28. OKSANEN J., BLANCHET F.G., KINDT R., LEGENDRE P., MINCHIN P.R., O'HARA R.B., SIMPSON G.L., SOLYMOS P., STEVENS M.H.H., WAGNER H. Vegan: Community Ecology Package, 2013.

29. 29.ZHEN Q., DENG Y., WANG Y., WANG X., ZHANG H., SUN X., OUYANG Z. Meteorological factors had more impact on airborne bacterial communities than air pollutants. Science of the Total Environment. 601-602: 703, 2017.

30. SEGATA N., IZARD J., WALDRON L., GEVERS D., MIROPOLSKY L., GARRETT W.S., HUTTENHOWER C. Metagenomic biomarker discovery and explanation. Genome Biology. 12 (6), R60, 2011.

31. HAEGEMAN B., HAMELIN J., MORIARTY J., NEAL P., DUSHOFF J., WEITZ J.S. Robust estimation of microbial diversity in theory and in practice. ISME Journal. 7 (6), 1092, 2013.

32. HARVEY R.W., METGE D.W., LEBLANC D.R., UNDERWOOD J., AIKEN G.R., BUTLER K., MCCOBB T.D., JASPERSE J. Importance of the colmation layer in the transport and removal of cyanobacteria, viruses, and dissolved organic carbon during natural lake-bank filtration. Journal of Environment Quality. 44 (5), 1413, 2015.

33. RAMANAN R., KANG Z., KIM B.H., CHO D.H., JIN L., OH H.M., KIM H.S. Phycosphere bacterial diversity in green algae reveals an apparent similarity across habitats. Algal Research. 8, 140, 2015.

34. KROHN-MOLT I., ALAWI M., FÖRSTNER K.U., WIEGANDT A., BURKHARDT L., INDENBIRKEN, D., THIEß M, GRUNDHOFF A., KEHR J., THOLEY A., STREIT W.R. Insights into microalga and bacteria interactions of selected phycosphere biofilms using metagenomic, transcriptomic, and proteomic approacs: Frontiers in Microbiology, 8, 1941, 2017.

35. NEWTON R.J., JONES S.E., EILER A., MCMAHON K.D., BERTILSSON S. A guide to the natural history of freshwater lake bacteria. Microbiology and Molecular Biology Reviews. 75 (1), 14, 2011.
36. NEWTON R.J., MCMAHON K.D. Seasonal differences in bacterial community composition following nutrient additions in a eutrophic lake. Environmental Microbiology. 13 (4), 88799, 2011.

37. MANCUSO F.P., SOFIE D., ANNE W., LAURA A., OLIVIER D.C. Diversity and temporal dynamics of the epiphytic bacterial communities associated with the canopy-forming seaweedcystoseira compressa(esper) gerloff and nizamuddin:. Frontiers in Microbiology. 7 (230), 2016.

38. ALMUTAIRI A. Spatial-temporal variations and diversity of the bacterioplankton communities in the coastal waters of Kuwait. Marine Pollution Bulletin. 100 (2), 699, 2015.

39. BUNSE C., BERTOSFORTIS M., SASSENHAGEN I., SILDEVER S., SJÖQVIST C., GODHE A., GROSS S, KREMP A, LIPS I, LUNDHOLM N, RENGEFORS K, SEFBOM J., PINHASSI J., LEGRAND C. Spatiotemporal interdependence of bacteria and phytoplankton during a baltic sea spring bloom. Front Microbiol, 7 (e89549), 517, 2016.

40. GARCÍA-MORALES R, PÉREZ-LEZAMA E.L, SHIRASAGO-GERMÁN B. Influence of environmental variability on distribution and relative abundance of baleen whales (suborder Mysticeti) in the Gulf of California[J]. Marine Ecology. 38 (6), e12479, 2017.

41. WYATT K.H., TELLEZ E., WOODKE R.L., BIDNER R.J., DAVISON I.R. Effects of nutrient limitation on the release and use of dissolved organic carbon from benthic algae in lake michigan. Freshwater Science, 33 (2), 557, 2014.

42. GUAN C., GUO X., CAI G., ZHANG H., YI L., WEI Z., ZHENG T. Novel algicidal evidence of a bacterium bacillus sp. 1p-10 killing phaeocystis globosa, a harmful algal bloom causing species: theory and applications in pest management. Biological Control, 76 (3), 79, 2014.

43. BEHRENFELD M.J., DONEY S.C., LIMA I., BOSS E.S., SIEGEL D.A. Annual cycles of ecological disturbance and recovery underlying the subarctic Atlantic spring plankton bloom. Global Biogeochemical Cycles. 27, 526, 2013.

44. CHEN H., ZHANG H., XIONG J., WANG K., ZHU X., ZHOU X., ZHANG D. Successional trajectories of bacterioplankton community over the complete cycle of a sudden phytoplankton bloom in the Xiangshan Bay, East China Sea. Environmental Pollution. 219, 750, 2016. 
